\title{
THESES ON PURE LANGUAGE AND POSTLITERATE TRANSLATION: WALTER BENJAMIN AND THE EXPERIENCE OF EXISTENTIAL EXILE IN LANGUAGE AND TRANSLATION
}

Gys-Walt van Egdom

Zuyd University College of Applied Sciences, Maastricht, Netherlands.

\begin{abstract}
It is the merit of Walter Benjamin to have spun a thread for what is now considered a desubjectivised theory of translation. In "Die Aufgabe des Übersetzers" (transl. "The Task of The Translator"), he advances the central thesis that all languages share one basic characteristic: slowly but steadily, they all move toward a point of convergence. To designate this point of convergence, Benjamin makes use of the elusive concept of "reine Sprache". Benjamin's tread will be taken up in this article, and it will be interwoven with what are coined "instances of postliteracy" as they are encountered in literature, only to form the tapestry that depicts not only the remembrance but also the ever-renewing promise of a purified language that constitutes the essence of a metaphysical exile in language.

Keywords: Philosophy of language. Philosophy of translation. Postliterate translation. Exile. Reine Sprache.
\end{abstract}

\section{TESIS SOBRE EL LENGUAJE PURO Y LA TRADUCCIÓN POSLITERARIA: WALTER BENJAMIN Y LA EXPERIENCIA DEL EXILIO EXISTENCIAL EN EL LENGUAJE Y LA TRADUCCIÓN}

Resumen: En « Die Aufgabe des Übersetzers » (trad. « La tarea del Traductor »), Walter Benjamin da origen a una teoría desubjetivizada de la traducción. En su ensayo, avanza la tesis de que todas las lenguas comparten una característica básica: todas están orientadas hacia un punto de convergencia, a saber : hacia la « reine Sprache » (trad. « lenguaje puro »). 
Siguiendo en los pasos de Benjamin, el presente artículo constituye una reflexión sobre esta noción esquiva de « lenguaje puro » y desea profundizar sobre la manifestación del parentesco suprahistórico de los idiomas en lo que se denominan, un tanto paradojicamente, «trazas literarias de postliterariedad». Dichas trazas arrojan una luz sin precedentes sobre el exilio metafísico del ser humano en el lenguaje.

Palabras claves : Filosofía del lenguage. Filosofía de la traducción. Posliterariedad. Exilio. Reine Sprache.

In "Die Aufgabe des Übersetzers", a text riddled with counterintuitive, sometimes (seemingly) contradictory statements, Walter Benjamin almost immediately hastens to point out that, when he speaks of the lives of languages and of art forms, one should readily avoid a figurative reading of the notion of "life" ("Die Aufgabe" 10-11). He insists that life is not only bestowed upon all things natural and organic, but that it is given, "in völlig unmetaphorischer Sachlichkeit"1, to everything with a history of its own. The meaning or, to use Benjamin's exact words, range of (a) life can only be understood adequately from the perspective of history (ibid.). With this audacious argument, the philosopher forges ahead with what might be called a "lebende" (living) or "lebendige" (lively) theory of translation.

If the abovementioned theory is to meet with aplomb all challenges it will be facing in the future, every word and every "notion" in this seminal essay should, thus, be read or, at least, readable through a "literal" lens. This is precisely the reason why I personally believe that, in order to gain a tangible sense of the theoretical, and even ontological ties that bind translation and exile together, might be fruitful to tap into Benjamin's "Aufgabe". ${ }^{2}$ I

\footnotetext{
${ }^{1}$ This fragment is loosely translated by Zohn as "an entirely unmetaphorical objectivity" ("The Task, 255).

${ }^{2}$ The pitfall of under-theorisation also lurks in the case of Benjamin. The story of Benjamin's life forms the ideal backdrop against which the contours of the translational and the exilic might appear. As is well known, he is not only the author of "Die Aufgabe des Übersetzers" - in which he singlehandedly dispelled all dominant ideas on translation -, he also worked as a translator. What is more, the philosopher also went into exile: the first time, in 1917, he bade his beloved Berlin goodbye, only to return to the German capital after
} 
have set out to seek a tractable understanding of Benjamin's theory of language and translation, and to relate this theory to some exemplary cases only at a later stage.

Sure enough, this will be no easy feat: choosing for a theoretical approach, and especially a theoretical approach to Benjamin's work can be tantamount to relapsing into mere esoteric habits, to a strict confinement to conundrum of a purely theoretical nature. From the outset, one should also be wary that, by homing in on Benjamin, an attempt to develop a sound theory in which the exilic is allowed full flay will no doubt cause relevant details to get awash in a sea of insignificance. It should be noted that I will not walk the reader through Benjamin's whole text.

These warnings are all the more weighty since Benjamin's sole excursion into the exilic, at least the only one in "Die Aufgabe", will unavoidably lead us to the notion of "reine Sprache" - like no other notion in Benjamin's rich oeuvre, "pure language" is elevated to a place of prominence, not only by the author, but also by his most devoted followers and his most indefatigable critics. The following passage, in which exile is not only cursorily introduced, but also instantly related to the task of the translator, will be our a point of departure: "Jene reine Sprache, die in fremde gebannt ist, in der eigenen zu erlösen, die im Werk gefangene in der Umdichtung zu befreien, ist die Aufgabe des Übersetzers" ("Die Aufgabe" 19). ${ }^{3}$

To keep us from going astray, two renowned philosophers will accompany us in the following pages. Immanuel Kant, who exerted an inestimable influence on Benjamin's thought, will be the first one to guide us. In the next section, Giorgio Agamben,

the threat of conscription was averted; the second time, his exile was less self-imposed: in March 1933, bereft of all hope of peace and freedom, he took leave of his Heimat, embarking on a journey that would end with his supposedly self-chosen death in Portbou, a Catalan border-town in the Spanish Pyrenees (cf. Gilloch). In this contribution, I have decided to steer clear of anecdotic evidence.; a "simple" case-like study is to be fended off, if an "existential" or "living" theory on translation and exile is to be given full play.

3 "It is the task of the translator to release in his own language that pure language which is exiled among alien tongues, to liberate the language imprisoned in a work in his re-creation of that work" ("The Task", 261).

Cad. Trad., Florianópolis, v. 38, n $^{0}$ 1, p. 157-180, jan-abr, 2018 
who has published extensively on Walter Benjamin and his theory of languages and whose own work bears an indelible Benjaminian imprint (cf. infra), will be in our company. It will only be at a later stage, when are able to, at the very least, glean the gist of the central notion of "pure language" and when the full weight of the above-cited words can be experience, that these philosophers will be bid adieu, as we will turn a sharp corner by shifting our attention to what will be dubbed "postliterate translation". It is hoped that, in the final section, a satisfactory answer to the profound question that will resonate ceaselessly in this article will be found. This question is: How do translation and reine Sprache relate to the condition humaine called "exile"?

\section{On "The Task"}

"Die Aufgabe des Übersetzers", a preface to Benjamin's translation of Tableaux parisiens, is a text that constantly eludes the reader's grasp. Perhaps the most difficult challenge to take up is that of picking up the basic thread of thought. In the first three paragraphs of the essay, Benjamin states, in a manner so abstract that the statement is easily overlooked, that, in order to save the phenomenon of translation itself, a proper take on translation is required ("Die Aufgabe" 9-10). Literary translations may well be produced only by human beings, and they may well be cultural (arte)facts, but, no matter how qualified the text sender or receiver is, nor the sender nor the reader can exert full control over it. In rough analogy to other art forms, literary translation is believed to be constantly within as well as out of reach. In other words, one should accept imposed limitations and allow translation to speak for and of itself, and perhaps even look for ways to make it speak up. This is why, according to Benjamin, the solution most propitious to the translational condition is, without exception, "desubjectivised" (cf. also Berman, "La traduction et la lettre" 83; id., "De la translation"; id., "La traduction et ses discours"; 
id., "L'Âge de la traduction"; Bloemen and Segers, "Het spreken" 19-23; id., "Vertaling" 640-642; Van Egdom, "Naar een ethiek" 125-162; id., "Wat er blijft" 48-49).

The essay becomes even more complex the moment the enigmatic notion of "pure language" is brought to the fore. We contend that the notion has probably only commanded such high interest among specialists because, by introducing it, the author has clearly succeeded at decimating his potential readership. Upon reading the first paragraph on pure language, one could be tempted to ridicule these passages as hogwash or simply to skip these passages altogether and cast around for passages that do not pose interpretive problems. After all, who is willing to accept that there is such a thing as a "suprahistorical" kinship between languages? And how is willing to accept that languages are growing toward a point of convergence? ("Die Aufgabe" 10-11). The fact remains that if one does not take the time to read and reread the passages on pure language, one is likely to remain in the dark with regards to the true stakes of Benjamin's living theory of translation.

Attention should therefore be drawn to Benjamin's own words. Having argued that the kinship of languages is manifested in translations, he points out that, rather than relying on some historical tie between languages, the "kinship" must be sought in an (inner) intention - in the texts' directionality as it were:

\begin{abstract}
Vielmehr beruht alle überhistorische Verwandtschaft der Sprachen darin, daß in ihrer jeder als ganzer jeweils eines und zwar dasselbe gemeint ist, das dennoch keiner einzelnen von ihnen, sondern nur der Allheit ihrer einander ergänzenden Intentionen erreichbar ist: die reine Sprache ("Die Aufgabe" 10-11). ${ }^{4}$
\end{abstract}

\footnotetext{
4 "Rather, all suprahistorical kinship between languages consists in this: in every one of them as a whole, one and the same thing is meant. Yet this one thing is achievable not by any single language but only by the totality of their intentions supplementing one another: the pure language" (“The Task", 256-257).
} 
A good many philosophers and scholars have been struck by the Messianic overtones in the text (cf. Derrida 224, 233; cf. de Man 76, 94; Kampff Lages, "Walter Benjamin” 22, 177). To them, it has not seemed much of a stretch to see the introduction of reine Sprache as an attempt to season the essay with Jewish mysticism. ${ }^{5}$ The interpretations of these authoritative theorists have inhibited a very fruitful debate and that their thoughts can never be unabashedly thrusted aside. In point of fact, Kampff Lages has even managed to touch upon the Judaic and interweave it, quite skilfully and surreptitiously, with the exilic ("Entre diferentes" 56).

Still, I contend that, by insisting too strongly on a Judaic or even Kabbalistic reading of "Die Aufgabe", one will continue to tread in a lockstep march toward a predetermined end. What is more, the recourse to the Messianic could be conceived as just another way of ignoring the theoretical conundrum of pure language, as, strictly speaking, such an interpretation cannot have any real bearing on empirical phenomena like translation. Instead of casting light on the matter, Benjamin's ideas are obfuscated; remarks become vague and elusive whenever the notion of pure language is to be given due emphasis. In this context, my own work serves as a good case in point: in the past, I have often cursorily interlinked the nebulous notion with what are deemed the most "practical" passages in the text: by so doing, "reine Sprache" seemed to gel with the seemingly instructive passages on "Wörtlichkeit" and "Freiheit" (cf. Van Egdom, "Retourtje tekst"; "Prolegomena" 684-688). Fortunately, the notion proves to be extremely resistant to repression, and almost impossible to extricate from its proper textual surroundings. As time passes, I realised that reine Sprache is not only the notion that causes Benjamin's theory to resurface in translation theory time and again; the notion is precisely what keeps the whole theory of language and translation afloat.

\footnotetext{
${ }^{5}$ Shortly after the outbreak of World War I, Walter Benjamin and Gershom Scholem struck up a friendship that is well-documented in a correspondence. Benjamin clearly looked up to his friend. As a result of this high esteem, he was soon deeply influenced by Scholem's Kabbalistic ideas (cf. Benjamin and Scholem; Scholem).
}

Cad. Trad., Florianópolis, v. 38, ${ }^{0}{ }^{1}$, p. 157-180, jan-abr, 2018 
To avoid repetition, I have decided to steer clear of the Messianic passages that permeate the text. Instead, I have tried to read Benjamin's text through a Kantian lens. For reasons of conciseness, my recent reading of Kant's critical trilogy ("Kritik der reinen Vernunft", "Kritik der praktischen Vernunft", "Kritik der Urteilskraft") will not be fully brought to bear on this paper. For the moment, I will have to make do with an hypothesis I have entertained since this tandem reading of "The Task" and Kant's trilogy. My hypothesis is the followingof "reine Sprache" is little more, but certainly nothing less than a regulative idea. Kant explains in his first "Critique" that a regulative idea is an idea or "goal" toward which the guidelines of our understanding are all directed (428). This point of reference lies beyond the ken of sensorial experience and is deemed indispensable if reason is to be elevated above the sense experience. The regulative idea is synonymous with the "as-if representation".

In other words, having read Benjamin through a Kantian lens, one is by no means condemned to the resigned conclusion that the event of pure language is nigh or inevitable. On the contrary, it remains unlikely that the sacred growth of language will ever be brought to a halt, with or without divine intervention. Therefore, I would like to insist upon the idea without this regulative principle, the "living" theory of translation, as envisioned by Benjamin, would never truly be in jeopardy. However, in its absence, translation would not tend in a definable or defined direction. This change or absence of a course), would indeed have farreaching consequences: translation, in its desubjectivised and organic conception, would cease to be a meaningful undertaking. Literally stripped of its sense, it could offer no viable alternative to the "dead theory of translation" (tote Theorie der Übersetzung, Benjamin, "Die Aufgabe" 13) - with its excessive focus on (static) meaning, on full mastery of the text. The absence of an albeit regulative teleological principle would leave this intricate theory, in which other notions, such as translatability, loyalty and freedom, are tampered with and turned on their heads, to sink. 
Be that as it may, we are still left with the arduous task of defining this regulative idea. The difficulty of answering this question is proportional to the overwhelming complexity of Benjamin's oeuvre. One would expect the answer to be spelled out in "Die Aufgabe des Übersetzers", but the essay only provides some clues. Pure language is the ideal end-product of the hallowed growth of languages, of the act of the convergence of languages. This convergence takes place in language in general and literature in particular. ${ }^{6}$ The following passage, quoted at length offers a glimpse of pure language, or, language in general in its opposition, or, rather, its relation to human language in particular: ${ }^{7}$

Bei den einzelnen, den unergänzten Sprachen nämlich ist ihr Gemeintes niemals in relativer Selbständigkeit anzutreffen, wie bei den einzelnen Wörtern oder Sätzen, sondern vielmehr in stetem Wandel begriffen, bis es aus der Harmonie all jener Arten des Meinens als die reine Sprache herauszutreten vermag. So lange bleibt es in den Sprachen verborgen. Wenn aber diese derart bis ans messianische Ende ihrer Geschichte wachsen, so ist es die Übersetzung, welche am ewigen Fortleben der Werke und am unendlichen Auflebender Sprachen sich entzündet, immer von neuen die Probe auf jenes heilige Wachstum der Sprachen zu machen: wie weit ihr Verborgenes von der Offenbarung entfernt sei, wie gegenwärtig es im Wissen um diese Entfernung werden mag (Benjamin, "Die Aufgabe" 14). ${ }^{8}$

\footnotetext{
${ }^{6}$ I would like to add that translation in no way influences the pace of this unfathomable growth. A good translation testifies to the ongoing movement of convergence, as it takes place in a language and, more precisely in literature.

${ }^{7}$ I resume here the line of thought represented by Slavoj Žižek with regard to Benjamin: "the point is not that human language is a species of some universal language 'as such', which also comprises other species [...]: there is no actually existing language other than human language - but, in order to comprehend this 'particular' language, one has to introduce a minimal difference, conceiving it with regard to the gap that separates it from language 'as such' (the pure structure of language deprived of the insignia of human finitude [...]") (239). 8 "In the individual, unsupplemented languages, meaning is never found in relative independence, as in individual words or sentences; rather, it is in a constant state of flux - until it is able to emerge as pure language from the harmony of all the various modes of inten-
} 
In the above-cited passage, one stumbles upon that word group that has vexed theorists for almost a century, "die Art des Meinens", and that is always set in opposition with its "evil" kin, "das Gemeinte". Together with the reference to Rudolf Pannwitz (20), this opposition has fuelled the debate on the proper Benjaminian course of translatorial action and has been a source of inspiration for the most concrete representations of pure language. Going about this passage in a slipshod fashion, it seems to suffer no doubt that in pure language the dissymmetry and irrationality of speech is simply dissolved, "sublated", so to speak, in such a manner that every language can be said to share an improbably similar Ausdruckspotenz. By way of example, the Dutch idiomatic expression "het lijdt geen twijfel" would become part of the English idiom (as well as any other idiom): i.e. the expression "it suffers no doubt" would probably not sound odd to those who have an elementary command of reine Sprache.

I find this take on pure language dissatisfactory. In addition to being dissatisfactory, the notion, conceived in this way, is bound to contribute very little to our understanding of exile in language and translation. Still, the ideas of theorist that have tried to fit pure language back into a "foreignisation code" should not be dismissed all too flippantly. With one eye firmly on the next section, the following passage, in which de Man discusses the "suffering" of the receiving language, a contraction-like pain that is symbolised in translation cf. "Die Aufgabe" 13), can easily be salvaged for profit:

What translation does, by reference to the fiction or hypothesis of a pure language devoid of the burden of meaning, is that it implies $[\ldots]$ the suffering of what one thinks of as one's own

tion. Until then, it remains hidden in the languages. If, however these languages continue to grow in this manner until the end of their time, it is translation which catches fire on the eternal life of the works and the perpetual renewal of language. Translation keeps putting the hallowed growth of languages to the test: How far removed is their hidden meaning from revelation, how close can it be brought by the knowledge of this remoteness?" (Benjamin, The Task, 74-75, Trans. Hans Zohn). 
[...] language. We think we are at ease in our own language, we feel a coziness, a familiarity, a shelter in the language we call our own, in which we think we are not alienated. What the translation reveals is that this alienation is at its strongest in our relation to our own original language, that the original language within which we are engaged is disarticulated in a way which imposes upon us a particular alienation, a particular suffering (82-83).

It speaks for itself that, in most poststructuralist accounts of "Die Aufgabe", the imposed alienation, the suffering of language, is caused by the (over)stretching of the Ausdruckpotenz of the receiving language. In order not to err in that same direction, attention will be now drawn to the work of Giorgio Agamben. With him, the journey will be continued and an answer will be sought to the questions why and how reine Sprache can be claimed to provoke a discomfort in one's own language.

\section{On the origins of language}

In the introduction, I have stated one of the reasons why Agamben's work might be particularly helpful. The Italian philosopher has succeeded in laying bare what I hold to be Benjamin's secret (or secretive) theory of language - a theory of which the seed had been sawn prior to the death of the Jewish philosopher, but which had yet to assume its definite shape in Benjamin's afterlife.

One question Agamben returns to in many of his writings (e.g. Il linguaggio, "Il silenzio", Infanzia) is unarguably metaphysical: How can it be that there is language in the first place? Theorists of language have found themselves enthralled with this question for centuries. In the $19^{\text {th }}$ century, philologists, linguists and philosophers alike were so caught up in their fascination with the origins of language that one important organization, the Société 
linguistique de Paris (1866), even forbade its members to take up the thorny issue. One would think that this brief historical overview bodes ill for Agamben's quest. That is precisely why Agamben decided to observe the "origins" from an unexpected angle.

Fully accepting the loss of an archè of language, the fact that speech is always-already spoken for, Agamben decided to focus all of his attention on the entrance into language of the individual. ${ }^{9}$ At this point, his famous experimentum linguae acquires prime importance (cf. "Il silenzio", 12; id., Infanzia , x). Straight away, the original question of origins is superseded by a range of (underlying) questions: How is language experienced by the infant? How does the infant "enter" language? When and, more importantly, how does the infant cease to be an in-fant - qui non farer? What is won with the entrance into language? And at what price is the infant granted permission to enter the realm of language? (cf. Infanzia)

Surely, the answer to the first question is not hard to come by. Before sounds start merging into patterns and turning into meaningful signs, language is little more than random noise to a suckling. However, the fact that, at that point, language is not yet experienced as (semantically) meaningful cannot account for the difference between the child's babbling and speech. To be able to detect palpable traces of (a) language, there should be a clean-cut difference between the two. Agamben comes up with a reasonable answer: language only becomes language the moment we can discern - consciously or subconsciously - an intention to signify (intenzione di significare) ("Il linguaggio" 47). According to Agamben, this is what lies at the root of meaningful communication. The infant ceases to be an infant, the moment $s /$ he recognises this intenzione in the words of others and the moment the sounds s/ he makes are accompanied by an albeit elementary or primordial intention to signify. One can certainly assume that this entrance into

${ }_{9}$ Remarkable as it may seem, Agamben never touches upon the precipitation into the Symbolic Order in psychoanalysis. It would take us too far afield here to expound the ideas of Lacan apropos the entrance into language (cf. Écrits 1966; Le Séminaire V 1998) and to examine their compatibility with Agamben's ideas.

Cad. Trad., Florianópolis, v. 38, nº 1, p. 157-180, jan-abr, 2018 
language is beneficial to a child. Upon entrance, it can engage in rudimentary communicative (inter)action. Still, this possibility to act and to interact with others comes at a price. What gets lost with the obtrusive presence of meaningful speech, is the intermediate "pure intention" of speech. Although Agamben recognises that, with this pure or purified intention, an imperceptible and, up to some point, unfathomable surplus is created in all communicative action, the original potentiality of language itself is forever beyond our grasp. Paradoxically enough, the price to be paid to speak a language is equal to that what makes a language a language in the first place (cf. "Il linguaggio"; id., "Infanzia"). I claim that what is coined the "(pure) intention to signify" in Agamben's work this driving impulse of language, of linguistic (inter)action - could straightforwardly and unequivocally be equated to reine Sprache.

In a circular way, we are now led back, via Kant and Agamben, to our point of departure. I firmly believe that, at this precise point, where a glimpse of language as such is offered, the communicability - das Dichterische - that, according to Benjamin, determines the form proper (Form) of translation can finally be seized upon ("Die Aufgabe" 9-10). It seems that the intenzione is what (a good) translation ultimately testifies to. Now the question should be raised: how does this intenzione relate to the human condition called "exile"? One need not go to great length to relate the two; it suffices to add Benjamin's own words to the equation: "Jene reine Sprache, die in fremde gebannt ist, in der eigenen zu erlösen, [...] ist die Aufgabe des Übersetzers" (19). Unmetaphorically speaking, pure intention is forced into exile in the uses of language and the translator is the one charged with the responsibility of recalling - reminiscing, revoking? - the exile. The sense of alienation that, as de Man suggests, is brought about by translation, is, in my opinion, nothing more than an estrangement from the language one considers one's own in its stark contrast to language as such, to language's pure potentiality. Read along these lines, Benjamin's rich oeuvre on language and translation, boiled 
down to its essentials, can be said to be a theoretical inquiry into the primordial linguistic uprooting of man.

\section{On postliteracy and postliterate translation}

Having established this link, we can now part ways with Agamben. It is now more or less clear that, although no one stands poised to grasp the pure intention of language, this trivial fact need not spell doom for his venerable theory of language and translation. In an attempt to mitigate the esotericism, a search of tangible testimonies to the pure intention is to be carried out. On the basis of the final paragraph of "Die Aufgabe" (20-21), it is safe to assume that the vanishing point of pure intention must persist forever as a stain in all instances of language use. This is all the more so, because it can be summoned up, as it were, in translation. The stains, so the argument goes in the final paragraphs of the Vorwort, form a particular pattern in experimental literature, where meaning is touched upon fleetingly (21). Names of authors that spring to mind most readily are Mallarmé, Rimbaud, Hölderlin, Beckett, Joyce. These authors all stood at the cradle of a literary genre that would see the light in the 20th and 21th century and that I define, hereunder, as "postliterate".${ }^{10}$ Compelled by the theme of this issue, I have decided to inquire into the manifestation of the pure intention, not in the work of the notorious writers mentioned above, not in purely "postliterate literature", but in instances of what I call "instances of postliteracy in translation".

I will provide three examples of these instances. Before doing so, some consideration will be bestowed upon the assumptions and claims that seem to underpin a theory of language and translation that I believe, first and foremost, to be worthy of Benjamin's stamp of approval, and that offers another insightful look into the, ontologically framed, linguistic displacement of man.

\footnotetext{
${ }^{10}$ Postliterate writings can be lumped together to form a nondescript "genre", which includes but is not restricted to lettrist and asemic writings (e.g. Isou, Lemaitre, Appel, Giacottino, Vekemans) at the fringes of the literary system.
} 
Seeing that, in his relentless search for a theory of language and translation, Benjamin never employs the term "postliteracy", it is paramount to outline the contours of the postliterate. The term "postliteracy" has been coined as early as the 1960's, but only now is the world becoming aware of the term's full complexity and its true relevance, as society is tending toward an era of postliteracy. In Understanding Media, Marshall McLuhan argued that the technological progress of his days unequivocally presaged that literacy, i.e. the skill of reading and writing, would, with time, become a secondary (although never completely dispensable) skill; oral communication, imagery and other direct means of communication would soon bask in the limelight (17). The advent of postliteracy has stunning implications for social-cultural phenomena.

In literature, a whole new dimension is added to the postliterate. In postliterate literature, the author simply outmanoeuvres meaningful communication and zeroes in on communicability itself (Vekemans 2012). It goes without saying that by indulging in the pleasures of the postliterate, the literary author risks the nemesis of literature as a whole. For many centuries, the success of literature has been entirely due to the literary knack, the dexterity of art of the author, and heavily dependent on the (degree of) literacy of the public. With the advent of postliteracy, these factors do no longer play a role: the lettrists' and asemics' concept of literature runs afoul of all literary conventions; the postliterate is centered on form - no more. In doing so, literary signs are systematically rendered illegible or, as Benjamin would probably have it, as legible per se.

When the phenomenon is dealt with in the context of translation, a number of salient elements of postliterate literature drop away. I intend to lay down the boundaries of postliteracy in translation as encountered in literary texts by dint of comparison. Postliteracy in translation bears great resemblance to homophonic translation, but there is a crucial distinction to be made. Whereas homophonic translation and instances of homophony in literary text clearly remain within the confines of (personally or culturally defined) aesthetics and/or ideology, solely rendering the aural beauty of a prototext or 
even seeking to harmonise the aural aspects of the prototext with the semantic possibilities of the target language, instances of postliteracy in translation, clearly working against the grain of a more or less conventional aesthetics, only envisage the experience proper of language, the experimentum linguae. Like homophonic translation, instances of postliteracy in translation mimic the sounds of a particular source language, but, in contradistinction to homophonic translation, these instances, ideally, prevent the intended reader from establishing a meaningful relationship as they are endowed with the pure potential(ity) of language. In other words, the instances, often transcriptions or transliterations, confront the reader with the abovementioned intenzione di significare, with pure language as the condition of possibility of linguistic (inter)action. By so doing, these instances testify to the linguistic displacement of man: we are confronted with something superfluous in a foreign language - this "something" is language as such -, and, concomitantly, with das Heimische of our own existence in language - the uncanny fact that our language displays no hospitality to language as such.

As promised, I will provide a few examples of "postliteracy in translation". The first exemplum, a photocopy of a comic called Goomer (Tejón), initially printed in El pequeño país and later bundled with other Goomer stories (in Moreno and Martínez), represents an entire (albeit very peripheral) subcultural genre: modern aljamiado literature. 


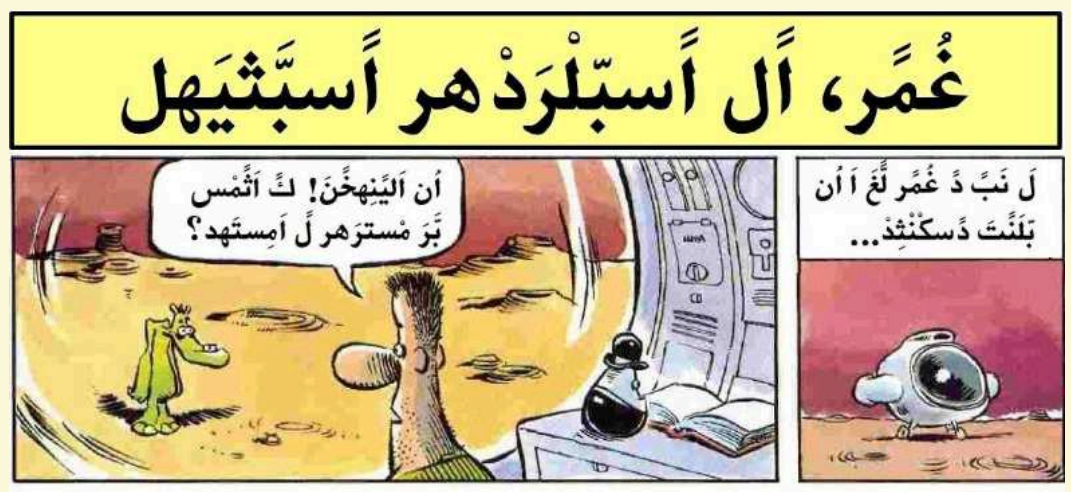

Fig. 1 Tejón, Fernando. Un comic: Goomer. "VerdaKrajono", https://ce9ca041-a-62cb3a1a-s-sites.googlegroups.com/site/verdakrajono/aljamia/goomer.pdf. Accessed 1 July 2016.

At first blush, this underground genre seems easy to mark off and categorise as "postliterate". Etymologically speaking, the noun "aljamiado" (or "aljamía”) refers to the foreign tongue (Schmid, 64-65). In aljamiado literature, a (foreign) Romance language is transcribed in Arabic (id.). However, one must tread lightly here: aljamiado texts should never be seen as the epitome of postliteracy. Upon closer inspection, one will note that modern aljamiado literature builds on the principles of the "aljamía morisca", a genre or, rather, a writing practice that, at one time, has been clearly ideologically embedded (cf. Wiegers, 1-14). Another objection to the typification of aljamiado literature as the epitome of postliteracy, is the fact that even the modern version seems intended for a Hispano-Arabic readership and, consequently, could be said to have a communicative intent. In other words, the pure language is never allowed to "shine" directly upon the Spanish original of Goomer. Nonetheless, these Arabic transcriptions of Spanish texts can be considered hyperbolic examples of postliteracy in translation, as these versions stay ever so close to the idea of "interlinearity" Benjamin espouses in "Die Aufgabe" (21).

Of more significance, is the second example: Nicolás Guillén's famous poem "Songoro, cosongo" (in Grünfeld): 


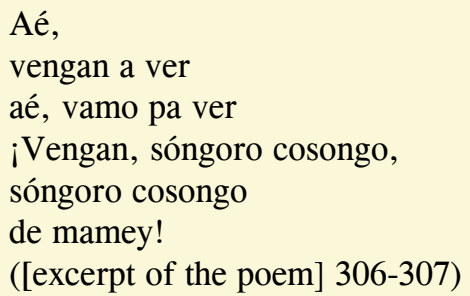

In the poem, verses in syncopated Cuban Spanish are yoked together with what at first glance seem to be simple jitanjáforas i.e. with "presumably nonsensical words and syllables" (Kutzinski, 179). However, when the readers takes a look at the first verse (Ay, negra, si tú supiera), the sounds can no longer be presumed nonsensical; the playful refrain seems to mimic what are irreverently called "black sounds" ("Sóngoro, cosongo..."). As such, they are never completely devoid of meaning: what is experienced through these transl(iter)ations of black sounds is the pure potential of (an unknown source) language. ${ }^{11}$

Most striking is the final example: a short passage taken from Call it Sleep, a novel by Henry Roth. The acclaimed American migrant novelist provides us with a textbook example of an instance of postliteracy in translation. In the novel, the protagonist, David, a young boy who lives in the Jewish slums of New York, is initiated into the Jewish faith. He recites his "blue book" and is, all of a sudden, engulfed by a sea of sounds:

Beshnas mos hamelech Uziyahu vawere es adonoi yoshav al kesai rum venesaw, vshulav malaiim es hahahol. Serafim omdim memal lo shash kanowfayim, shash kanowfayim lawehhad, beshtayim yahase fanav unishtayim yahase raglov uvishtayim yahfaif.

\footnotetext{
${ }^{11}$ The second example could also be said to fall somewhat short of the mark. The pure potential of these sounds is laid on the line by the author himself, who uncovers a layer of specific meaning: what an African tongue can make of the title of the poem is "Good morning" (Guillén, 87-88).
} 
All his senses dissolved into the sound. The lines [...] thundered in his heart with limitless meaning, rolled out and flooded the last shores of his being (255).

By reading (and re-reading) this fragment, the protagonist, who clearly does not master the language of "his people" yet, testifies to the pure intention of the text, or, to resonate David's own words, to its "limitless meaning". These words will have an unsettling effect on David, because, by experiencing this pure intention, he is remembered of his origins that are forever lost.

\section{Conclusion}

Maurice Blanchot, whose ideas are highly compatible with those of Benjamin, once stated most appositely that: "L'exilé ne s'accommode pas de l'être, et pas davantage de renoncer à l'être, et pas davantage de se faire de l'exil une manière de résidence." (Après Coup 94) ${ }^{12}$ One can always become a stranger, he maintains, but from the moment our strangeness, our estrangement has been registered, one can never and nowhere cease to be a stranger. The difficulty of shaking off strangeness seems to be Blanchot's main thrust in his further ruminations on exile: once exiled, one cannot learn to live with it - let alone, do away with it. ${ }^{13}$

12 "The exile cannot accommodate himself to his condition, nor to renouncing it, nor to turning exile into a mode of residence." (Blanchot, "Vicious circles" 66)

${ }^{13}$ I admit that I did not want to go down a theoretical rabbit hole in this conclusion. I realise that the fragment in Après coup could easily be pitted against an oft-cited passage in L'entretien infini. Whereas in the first fragment Blanchot goes to some length to prevent anchorage of the exilic in ontology, he seems all too eager to interlink exile and ontology in the second fragment. The fragment reads as follows: "S'il faut se mettre en route et errer, est-ce parce qu'exclus de la vérité, nous sommes condamnés à l'exclusion qui interdit toute demeure ? N'est-ce pas plutôt que cette errance signifie un rapport nouveau avec le « vrai » ? N'est-ce pas aussi que ce mouvement nomade [...] s'affirme non pas comme l'éternelle privation d'un séjour, mais comme une manière authentique de résider [...]? Comme si l'état sédentaire était nécessairement la visée de toute conduite !" (185-186, ["if one must set out on the road and wander, is it because, being excluded from the truth, we are condemned to the exclusion that prohibits all dwelling? Or would not this errancy rather signify a new rela- 
Through a literal reading of "Die Aufgabe" and by seeking two allies in a quest to further theour understanding of the capital notion of reine Sprache, I have tried to clarify that a similar point is made by Benjamin, only in a cruder and more fundamental fashion: apropos language, he points out that one can step over the threshold of the symbolic, but upon entrance - from the word "mama" or "dada" - one can nevermore leave, never reach out of the symbolic order. Unbeknownst to oneself, ones forces oneself into the exile of language, making a return impossible. No longer having recourse to a language that is pure (rein), to a purified intention, one becomes the odd one in.

Benjamin maintains that, despite man's existential displacement, there need not be a reason for despair. With Kant, a major source of inspiration of Benjamin's, I have argued that pure language, conceived as a regulative idea, holds the promise of a return. The responsibility lies with the translator to "renew" the promise by interpassively contributing to the annulment of exile. Still, the optimism should be curbed: those who cling on too strongly to the Messianic tend to lose sight of the "regulative" function of pure language. One look at the notion suffices to understand that it is, in the strictest sense of the word, a "pre-post-erous" notion, simultaneously pointing toward a pure past, a past that possibly never was present, and toward a future that probably never will see the light of (a) present day. ${ }^{14}$ What transforms this mythical concept into a regulative idea is the promise that lies at the root of Messianic thought: even if the promise is destined to remain unfulfilled, the promise will abide, remain in place as a promise, setting into motion the desire proper of a return.

tion with 'truth'? Doesn't this nomadic movement [...] affirm itself not as the eternal privation of a sojourn, but rather as an authentic manner of residing [...]? As though the sedentary state were necessarily the aim of every action!" (“The Infinite Conversation” 127-128)]).

${ }^{14}$ In L'entretien infini, Blanchot is slightly more positive about the overcoming of exile in language and "in real-time": "La parole est la terre promise où l'exil s'accomplit en séjour" (186, ["[S]peech [...] is the Promised Land where exile fulfills itself in sojourn ("The Infinite Conversation" 128, cf. "Entre diferentes" 56). 
By providing three examples of instances of postliteracy in translation, I hope to have casted new light on Benjamin's theory of language and translation, and to have steered clear of esotericism. My main objective was to bring into view, in a very concrete manner, the renewal of the promise of a return to the infantine abode in these instances of postliteracy. In the three exemplary fragments, in which reine Sprache is allowed to resonate and bound to collide with concrete language(s), a tangible testimony is given of man's existential exile in language: the pureness of postliteracy is experienced and rubs off on source and target language alike, producing a discomfort in a language called our own; as a consequence, the postliterate attracts the attention to the fundamental linguistic displacement of man, but, in a subversive way, it also points toward a recalling of this exile.

\section{References}

Agamben, Giorgio. Il linguaggio e la morte. Turin: Einaudi, 1982.

. "Il silenzio delle parole." In cerca di frasi vere. Ed. Ingeborg Bachmann. Rome-Bari: Laterza (1989): 5-15.

. Infanzia e storia. Turin: Einaudi, 2001.

Benjamin, Walter. "Die Aufgabe des Übersetzers." Gesammelte Schriften. Vol. 4.1. Eds. Rolf Tiedemann and Hermann Schweppenhäuser. Frankfurt am Main: Suhrkamp (1972): 9-21.

. "The Task of the Translator." Illuminations. Trans. Harry Zohn. London-Sydney: Random House (1999): 70-82. 
Benjamin, Walter \& Gershom Scholem. The Correspondence of Walter Benjamin and Gershom Scholem, 1932-1940. Ed. Gershom Scholem, Trans. Gary Smith and André Lefevere. New York: Schocken, 1989.

Berman, Antoine. "La traduction et la lettre ou l'auberge du lointain." Les tours de Babel: essais sur la traduction. Ed. Antoine Berman. Mauvezin: TransEuropRepress (1985): 33-150.

. "De la translation à la traduction." TTR: Traduction, terminologie, rédaction 1.1 (1988): 23-40.

. "La traduction et ses discours." Meta 34, 4 (1989): 672-679.

. L’Âge de la traduction: 'la tâche du traducteur' de Walter Benjamin, un commentaire. Saint-Denis: Presses Universitaires de Vincennes, 2008.

Blanchot, Maurice. L'entretien infini. Paris: Gallimard, 1972.

. The Infinite Conversation. Trans. Susan Hanson. Minneapolis: University of Minnesota, 1993.

. Après coup, précédé de Le Ressassement éternel. Paris: Minuit, 1983.

. Vicious Circles. Trans. Paul Auster. Barrytown-New York: Station Hill, 1985.

Bloemen, Henri, and Winibert Segers. Het spreken van de vertaling. KortrijkHeule: UGA, 2012

. "Vertaling, wezen en teleurstelling." Belgisch Tijdschrift voor Filologie en Geschiedenis/Revue belge de Philologie et d'Histoire 90.3 (2012): 639-646.

De Man, Paul (1986). “'Conclusions'”: Walter Benjamin's 'The Task of the Translator'." The Resistance to Theory, Paul de Man. Minneapolis: University of Minnesota (1986): 73-105. 
Derrida, Jacques. “Des tours de Babel.” Psyché: Inventions de l'autre, Jacques Derrida. Paris: Galilée (1987): 203-35.

Grünfeld, Mihai. “Nicolás Guillén, Cuba, 1902-1989.” Antología de la poesía latinoamericana de vanguardia. Ed. Mihai Grünfeld. Madrid: Hiperión (1995): 303-346.

Guillén, Nicolás. Sóngoro cosongo. Quito: Libresa, 1997.

Kampff Lages, Susana. "Entre diferentes culturas, entre diferentes tradições - o pensamento constelar de Walter Benjamin." Cadernos de Letras 22 (2007): 49-67.

. Walter Benjamin: tradução e melancolia. São Paulo: Editora da Universidade de São Paulo, 2007.

Kant, Immanuel. "Kritik der praktischen Vernunft." Gesammelte Werke. Akademie-Ausgabe, Vol. 5. Berlin: Reimer (1902): 1-164.

. "Kritik der Urteilskraft." Gesammelte Werke. Akademie-Ausgabe. Berlin: Reimer 5 (1902): 165-485.

. "Kritik der reinen Vernunft." Gesammelte Werke. Akademie-Ausgabe. Berlin: Reimer 3 (1911).

Kutzinski, Vera. Sugar's Secrets. Race and the Erotics of Cuban Nationalism. Charlottesville-London: UP Virginia, 1993.

Lacan, Jacques. Écrits. Paris: Seuil, 1966.

Lacan, Jacques. Le Séminaire, Livre V: Les Formatons de l'inconscient, 19571958. Ed. Jacques-Alain Miller. Paris: Seuil, 1998.

McLuhan, Marshall. Understanding Media: Extensions. Toronto: McGraw Hill, 1964. 
Moreno, Nacho and Ricardo Martínez. El planeta de mi Elma. El País/Altea: Madrid, 1990.

Roth, Henri. Call it sleep. New York: Robert Ballou, 1934.

Scholem, Gershom. Walter Benjamin: The Story of a Friendship. Trans. Harry Zohn. New York: Schocken, 1987.

Schmid, Beatrice. "La transcripción de datos judeoespañoles de fuentes aljamiadas." Transcrivere la lingua/Transcribir la lengua. Eds. Yvette Bürki and Elwys DeStefani. Bern: Peter Lang (2006): 63-84.

Tejón, Fernando. "Un comic: Goomer." VerdaKrajono, https://ce9ca041a-62cb3a1a-s-sites.googlegroups.com/site/verdakrajono/aljamia/goomer.pdf. Accessed 1 July 2016.

Van Egdom, Gys-Walt. "Retourtje tekst. 'Intencie' als leidraad bij de vertaling van Alejandra Pizarniks poëzie.” Filter, Tijdschrift voor Vertalen en vertaalwetenschap 19. 4 (2012): 67-75.

. "Prolegomena tot een nieuwe conceptie van vertaalbaarheid." Belgisch Tijdschrift voor Filologie en Geschiedenis/ Revue Belge de Philologie et d'Histoire 90.3 (2012): 659-730.

. "Wat er blijft, verblijft en overblijft in vertaling. De 'spookethiek' van Antoine Berman." Een ethiek van de vertaling. Eds. Henri Bloemen and Winibert Segers. Kortrijk-Heule: INNI (2015): 47-56.

. "Naar een ethiek van de literaire vertaling." [Dissertation] Vrije Universiteit Brussel, 2015.

Vekemans, Dirk. "Aan elke zin ontheven - Asemisch schrijven als uitzonderingstoestand", Samplekanon, 2012. http://samplekanon.com/?p=1197. Accessed 6 December 2016

Weber, Samuel, Benjamin's -abilities. Cambridge: Harvard University, 2008. 
Wiegers, Gerard. Islamic Literature in Spanish and Aljamiado. Yça of Segovia (fl. 1450), His Antecedents and Successors. Leiden: Brill, 1994.

Žižek, Slavoj. Towards a New Foundation of Dialectical Materialism. London: Verso, 2015.

Recebido em: 24/08/2017 Aceito em: 29/10/2017 Publicado em janeiro de 2018

Gys-Walt van Egdom holds a doctor's degree in Linguistics and Literary Studies and a master's degree in Translation Studies. He is a lecturer and researcher at Zuyd University of Applied Sciences (Maastricht School of Translation and Interpreting) and is also affiliated to Vrije Universiteit Brussel. He is researcher at the Centre of Expertise Translation Didactics (Zuyd-ITV) and Centre of Expertise International Relationship Management (Zuyd) and a member of the Centre for Literature in Translation (VUB). Zuyd University. Maastricht, Limbourg, Netherlands. E-mail: gijs-walt.vanegdom@zuyd.nl 